HStud 25 (2011)2, 175-183 DOI: 10.1556/HStud.25.2011.2.1

\title{
DEALING WITH COMMUNIST PAST: THE CASE OF ROMANIA
}

\author{
VLADIMIR TISMANEANU \\ University of Maryland \\ Baltimore, MD, USA
}

\begin{abstract}
This article analyzes the significance of the activity of the Presidential Commission for the Analysis of the Communist Dictatorship in Romania (PCACDR) and the impact of its report on the basis of which the communist regime was condemned as criminal and illegitimate. The author also situates the Romanian case within the larger discussions on the role of overcoming a traumatic past in post-authoritarian democracies. PCADCR rejected outright the practices of institutionalized forgetfulness and generated a national debate about long-denied and occulted moments of the past. The Commission's Final Report answered a fundamental necessity, characteristic of the post-authoritarian world, that of moral clarity. It set the ground for the revolutionizing of the normative foundations of the communal history, imposing the necessary moral criteria of a democracy that wishes to militantly defend its values.
\end{abstract}

Keywords: communism, memory, dealing with the past, legitimacy, Leninist legacy, perpetrator, democracy

On December 16th 2006, the Romanian President condemned the communist regime as "criminal and illegitimate" throughout its existence. His speech was based upon a Final Report drafted by a Commission for the Analysis of the Communist Dictatorship in Romania (PCACDR). I had the honor of chairing this commission. From 2006 until present, the topic of dealing with communist past has been at the forefront of public debate in the country. In the present article I will analyze the significance of the commission's activity and the impact of its report, while situating it within the larger discussions on the role of overcoming a traumatic past in post-authoritarian democracies.

For the first time in Romania's contemporary history, the PCADCR rejected outright the practices of institutionalized forgetfulness and generated a national debate about long-denied and occulted moments of the past (including instances of collaboration, complicity, etc). The activity of the commission was "a state, public history lesson" during which the "truth" about the communist totalitarian experienced was "officially proclaimed and publicly exposed" (Ash, 2002), that 
is, acknowledged. It was an exercise of "sovereignty over memory" (Snyder, 2002) an attempt to set the stage for resolving what Tony Judt called the "double crisis of memory":

\begin{abstract}
On the one hand cynicism and mistrust pervade all social, cultural and even personal exchanges, so that the construction of civil society, much less civil memory, is very, very difficult. On the other hand there are multiple memories and historical myths, each of which has learned to think of itself as legitimate simply by virtue of being private and unofficial. Where these private or tribal versions come together, they form powerful counterhistories of a mutually antagonistic and divisive nature (Judt, 2002, 173).
\end{abstract}

The post-1989 practice of state-sponsored amnesia created two main dangers: the externalization of guilt and the ethnicization of memory. As both Dan Diner and Gabriel Motzkin argued, the process of working through the communist past raises a crucial problem: "How can crimes that elude the armature of an ethnic, and thus-long term, memory be kept alive in collective remembrance?" (Diner, 2003, 86) The domination and exterminism of a communist regime generally affected all strata of the population; terror and repression were engineered from within against one's people. Therefore, "the lack of specific connection between Communism's theoretical enemy and its current victims made it more difficult to remember these victims later" (Motzkin, 2003, 202). When no Aufarbeitung took place, the memory field was left for 'alternative' interpretations.

On the one hand, the evils of the communist regime were assigned to those perceived as aliens: the Jews, the national minorities, or other traitors and enemies of an organically defined nation. Such line of perverted reasoning unfolded immediately after my nomination as Chair of the PCACDR. I became the preferred target of verbal assault, including scurrilous slanders and vicious anti-Semitic diatribes, targeted the commission's president (Tismaneanu, 2006, 2007). The Commission itself was labeled as one made up of foreigners (alogeni); entire genealogies were invented for various members of this body, all just to prove the fact that the 'real perpetrators' are forcing upon the nation a falsified history of its suffering. Upon delivering the condemnation speech, the President and some members of the Commission were showered with threats and imprecations by the representatives of the xenophobic and chauvinistic Romania Mare Party. Unfortunately, as an indication of the deep-rooted malaise of memory in Romania, very few MPs of the other mainstream parties publicly objected to this behavior (Nicolae Vacaroiu, then President of the Romanian Senate, did nothing to stop this circus).

A further proof of narrow-mindedness came a few months later, when a critic of the Final Report, found no qualms in stating that: "if it weren't for the stupid, but violent reactions of nationalists, extremists, etc., the Report would have 
passed almost unnoticed by the public opinion that counts, the one from which one can expect change" (Șiulea, 2007). In reality, however, such utterances are indicative of a very interesting, though worrisome, post-condemnation phenomenon: the argumentative coalition against the Final Report of a self-proclaimed 'new left' with the national-Stalinists (those who perpetuate the topoi of the pre-1989 propaganda or those who are nostalgic for Ceaussescu's "Golden Age"), and with the fundamentalist Orthodoxists. Such alliance can be explained in two ways: first, these are the faces of resentment, the people who were forced to confront their own illusions and guilt or those who stubbornly refuse to accept the demise of Utopia (what in Germany fell in the category of anti-antiutopianism) (Müller, 2000); second, these are those for whom, mostly because of ignorance, dealing with the communist past can be resumed to mechanical instrumentalization, for whom this redemptive act is a 'strategic action'. The result of their mainly journalistic flurries is one that does not surprise the sober observer: a counter-trend of malendtend $u$ revisionism that does represent, because of its promise of facile remembrance, a latent danger for continuation of the strategy of legal, political, and historical Aufarbeitung.

The other danger that lies in a mis-memory of communism is the development of "two moral vocabularies, two sorts of reasoning, two different pasts": that of things done to 'us' and that of things done by 'us' to 'others'. Tony Judt sees this practice as the overall post-war European syndrome of "voluntary amnesia" (Judt, 2002, 163-6; Judt, 2005). In Romania, its most blatant manifestation was the denial of the Holocaust, of the role of the Romanian state in the extermination of the Jews. ${ }^{1}$ But another manifestation of the syndrome can also be found in relation with the communist past. One of the master-narratives after 1989 was that, because of the Soviet imposition, the regime was not part and parcel of the national history. It was a protracted form of foreign occupation during which the population was victimized by foreigners and rogue, inhuman, bestial individuals. This discourse was and is based upon the topical trinity of they \& it vs. us. In later years it went through finer qualifications: on the one hand, the "High Stalinism" period (roughly 1947-53, with maybe the added value of 1958-62), the so-called "haunting decade", was blamed on the "Muscovites" (mostly Pauker, Luca, Chisinevschi) and, sometimes, but in a redemptive key on Gheorghiu Dej as well (who also wears a historiographical cap of national awakener on the basis of his later years in power). On the other hand, the Ceaușescu period is seen as one of patriotic emancipation and self-determination from under the Kremlin iron heel. The distortions of such 'healthy path' are mostly blamed on Ceaușescu's personality cult. It is no surprise that in some quarters, his execution was seen as the end of communism, of its evils and/or legacy. The overall conclusion of such normalizing gymnastics was similar to the above-discussed issue: the criminality of the 
regime lay in its anti-national past, while its development of the Nation's interest and being can be separated from the degeneration of its leaders.

President Băsescu charged the commission with the task of producing a rigorous and coherent document that would examine the main institutions, methods, and personalities that made possible the crimes and abuses of the communist regime. In addition to its academic tasks, the commission was meant to pass moral judgment on the defunct dictatorship and invite a reckoning with the past, even though this would entail a painful, albeit inevitable, acknowledgement of crimes against humanity and other forms of repression. First of all, this initiative is a fundamentally symbolic step toward national reconciliation by means of clarifying and dealing with the past. Only in this way can Romanian society overcome the fragmentation typical of the "legacy of Leninism". ${ }^{2}$ President Băsescu advocated a reinstitutionalization freed from the burden of the party-state continuities and the possibility for laying the foundation of a "posttotalitarian legitimacy" (Müller, $2000,258)$. It is his belief that only in such fashion can one develop the not-yet-attained national consensus. The process of Vergangenheitsbewältigung that it initiated imposes criteria of accountability fundamental to the re-enforcement and to the entrenchment of democratic values in Romanian society. For, as Jan-Werner Muller argued, "without facing the past, there can be no civic trust, which is the outcome of a continuous public deliberation about the past" (Müller, 2002, 33-4).

Following upon Ken Jowitt's footsteps, I consider that the fundamental Leninist legacy in Eastern Europe was the total fragmentation of society, the break of the civic bonds and consensus necessary for a healthy, democratic life (Jowitt, 1992; Tismaneanu et al., 2006). The tumultuous post-1989 years in Romania are the perfect proof for this thesis: sectarian interests, widespread authoritarian tendencies within the public and political spheres, anomie, etc., were all rooted in forgetfulness. The CPACDR did not find new 'truth', but it lifted the veil of denial over those truths that were widely known but stubbornly unacknowledged. ${ }^{3}$ In a country where the legal measures against the abuses perpetrated during the communist years are close to nonexistent and where the judicial system is rather weak and corrupted, it can be said that the Commission created the future prospects for justice.

The Final Report, besides its detailed accounts on the functioning of the various mechanisms of power and repression, also named names; it listed the most important people who were guilty for the evils of the regime. It did not stigmatize any group, its purpose was not inquisitorial; but it engaged in a truth-telling process essential for understanding the nature of responsibility for crimes and suffering under communism. In Priscilla Hayner words: "where justice is unlikely in the courts, a commission plays an important role in at least publicly shaming those who orchestrated atrocities". It revitalized the principle of accountability, fundamental for democracy's survival (Hayner 2002, 82-7). ${ }^{4}$ Considering the present 
political environment in Romania, I can only reiterate Chilean President Patricio Aylwin dictum upon the creation of the Retting Commission: justice as far as possible (justicia en la medida de lo posible). The moral-symbolic action is after all one of the four types of retributive justice (the others being the criminal, the noncriminal, and the rectifying aspects) (McAdams, 2001).

The reverberations of the past are part of contemporary polemics and define competing visions of the future. It is quite often in relation to the past, especially a traumatic one, that political actors identify themselves and engage in competitions with their opponents. Reviewing Jan T. Gross's book Fear, David Engel wrote,

\begin{abstract}
Unless Polishness, whatever its constituent characteristics, is transmitted from generation to generation through mother's milk, as it were, nothing that Gross or anyone else might say about any part of the Polish community in 1946, 1941, or any other year more than six decades in the past necessarily reflects upon any part of the community today. It can do so only to the extent that the present community continues to affirm the values implicated in past events. Thus Fear or any other work of history can legitimately be neither offered nor read as a vehicle for contemporary self-examination except insofar as it prompts contemporaries to question strongly whether they remain committed to those values (Engel, 2007, 538-9). ${ }^{5}$
\end{abstract}

The postcommunist debates on the past should be seen as indicators of contemporary ideological cleavages and tensions, confirming Jürgen Habermas's analysis of the public use of history as an antidote to oblivion, denial, and partisan distortions:

It is especially these dead who have a claim to the weak anamnestic power of a solidarity that later generations can continue to practice only in the medium of a remembrance that is repeatedly renewed, often desperate, and continually on one's mind (Habermas, 1989, 233).

The PCACDR's Final Report's approach on the category of perpetrator was focused on three types that have been consistently ignored by those who blame the document for a so-called blanket condemnation. According to Cosmina Tănăsoiu, "one can identify those guilty for the thousands of dead and deported" (i.e., top Party officials, cabinet ministers, police commanders, high-level magistrates), those "guilty for the annihilation of diaspora dissent" (i.e., the heads of the external services of the secret police and counter-intelligence), and those "guilty for the indoctrination of the population" (the largest category, ranging from Party members and cabinet ministers to writers and poets) (Tănăsoiu, 2007, 65).

Additionally, the Final Report signaled out those who responsible, after 1989, for the manipulating and forging the truth in order to preserve their power and 
continue, by means of an "original democracy", the fateful structures and the interest groups dominant during the last decade of the party-state rule. I think that this last section of the IIIrd part of the Report, was fully justified by the specific post-1989 history of Romania, one marred with moments of critical "managed anarchy" (the miners' trips to Bucharest and the pyramidal financial schemes), by the quasi-bankruptcy of the market economy, by infrastructural retardation. Overall however, the individual and his inalienable rights were the main reconstitutive focus of the Final Report. The members of the PCACDR refused the principle of collective guilt and/or punishment.

The PCACDR was a tool for mediation between the construction of a legitimate post-dictatorial state and the finalisation - or at least the setting under way of the judicial act. The present level of transition may be a compromise, but it must be fundamentally conditioned by knowledge of the criminal past and by the moral recognition upon which legitimate society is built. I therefore consider Charles Villa-Vicencio's conclusion perfectly justified, namely that the truth that a commission makes public and official is not just a working through of the previous regime, but also the criterion for limiting and framing the compromise of the transitional period (Vicencio 2003, 37). The shared historical judgment and memory such a Commission offers can open the path toward a more profound post-transitional political realignment.

In conclusion, I believe that the condemnation of the communist regime in Romania was a moment of civic mobilization. Generally speaking, de-communization is, in its essence, a moral, political, and intellectual process. These are the dimensions that raise challenges in contemporary Romanian society. The PCACDR's Final Report answered a fundamental necessity, characteristic of the post-authoritarian world, that of moral clarity. Without it one would multiply the cobweb of lies crushing us, the impenetrable mist that seemed to forever last. This state of moral perplexity inexorably turns into cynicism, anger, resentment and despair. The shock of past unveiled is inevitable. The Final Report identified many features of guilt, in relation to the communist experience, that have never before been under scrutiny. It offers a framework for shedding light upon what Karl Jaspers called "moral and metaphysical guilt" - the individual's failure to live up to his or her moral duties and the destruction of solidarity of social fabric (Liiceanu, 2007). This, in my opinion, is the angle from which one can see to the connection between condemnation initiative and politics. In the words of Charles King,

The commission's chief tasks had to do with both morality and power: to push Romanian politicians and Romanian society into drawing a line between past and present, putting an end to nostalgia for an alleged period of greatness and independence, and embracing 
the country's de facto cultural pluralism and European future (King, 2007, 722).

Such matters considered, the PCACDR was indeed a political project through which both the acknowledgement and conceptualization of the 1945 to 1989 national traumatic experience were accomplished, whilst those responsible for the existence of communism as a regime in Romania were identified.

The PCACDR created a document where responsibility for the past was claimed and individualized. There are hardly other ways of reconstructing Gemeinsamkeit, that is, the social cohesion and communion destroyed by the atomization brought about in the communist regime. As I have already stated, the Final Report was written with analytical rigor, with compassion for the victims, and in full awareness of the trauma both incumbent in the past and in the act of remembrance itself. PCACDR aimed at a synthesis between understanding the traumatic history through an academic praxis that presupposes distance from the surveyed subject, and empathizing with the people who suffered because of the crimes and abuses of the dictatorship. The commission pursued a reconstruction of the past along the dichotomy distance-empathy, focusing upon both general and individual aspects of the past. The Final Report fixed the memory of the totalitarian experience in place and in time, it overcame the burden of the denial of memory, of institutionalized amnesia. It set the ground for the revolutionizing of the normative foundations of the communal history, imposing the necessary moral criteria of a democracy that wishes to militantly defend its values.

\section{References}

Diner, Dan (2003) 'Remembrance and Knowledge: Nationalism and Stalinism in Comparative Discourse' in Dubiel, Helmut and Gabriel Motzkin (eds) The Lesser Evil: Moral Approaches to Genocide Practices (Portland: Frank Cass), 85-97.

Engel, David (2007) 'On Continuity and Discontinuity in Polish-Jewish Relations: Observations on Fear' East European Politics and Societies, Vol. 21, No. 3, Summer, 538-9.

Gross, Jan T. (2006) Fear: Anti-Semitism in Poland after Auschwitz - An Essay in Historical Interpretation (New York: Random House).

Habermas, Jürgen (1989) The New Conservatism: Cultural Criticism and the Historians' Debate, ed. and trans. by Shierry Weber Nicholsen (Cambridge MA: MIT Press).

Hayner, Priscilla B. (2002) Unspeakable Truths: Facing the Challenge of Truth Commissions (New York: Routledge).

Jowitt, Kenneth (1992) New World Disorder: The Leninist Extinction (Berkeley: University of California Press).

Judt, Tony (2002) 'The Past is Another Country: Myth and Memory in Post-war Europe' in Istvan Deak, Jan T. Gross and Tony Judt (eds) The Politics of Retribution in Europe. World War II and Its Aftermath (Princeton, NJ: Princeton University Press) 293-324. 
King, Charles (2007) 'Remembering Romanian Communism' Slavic Review, Vol. 66, No. 4, Winter, $718-23$.

Liiceanu, Gabriel (2007) Despre ură (București: Humanitas).

McAdams, James A. (2001) Judging the Past in Unified Germany (New York: Cambridge University Press).

Motzkin, Gabriel (2003) 'The Memory of Crime and the Formation of Identity' in Helmut Dubiel and Gabriel Motzkin (eds) The Lesser Evil: Moral Approaches to Genocide Practices (Portland: Frank Cass) 196-210.

Müller, Jan-Werner (2002) 'Introduction: The Power of Memory, the Memory of Power, and the Power over Memory' in Jan-Werner Müller (ed.) Memory and Power in Post-War Europe: Studies in the Presence of the Past (Cambridge, UK: Cambridge University Press) 1-35.

Müller, Jan-Werner (2007) Constitutional Patriotism (Princeton: Princeton University Press).

Șiulea, Ciprian (2007) 'Imposibila dezbatere. Încrâncenare și optimism în condamnarea comunismului' Observator Cultural, July 5th, No. 385.

Snyder, Timothy (2002) 'Memory of Sovereignty and Sovereignty over Memory: Poland, Lithuania and Ukraine, 1939-1999' in Jan-Werner Müller (ed.) Memory and Power in Post-War Europe: Studies in the Presence of the Past (Cambridge: Cambridge University Press).

Tănăsoiu, Cosmina (2007) 'The Tismaneanu Report: Romania Revisits its Past' Problems of Post-Communism Vol. 54, No. 4, 60-9.

Tismaneanu, Vladimir (2006) Democrație și memorie (București: Curtea Veche).

Tismaneanu, Vladimir (2006) Refuzul de a uita (București: Curtea Veche).

Tismaneanu, Vladimir, Marc Howard and Rudra Sil (eds) (2006) World Order After Leninism (Seattle: University of Washington Press).

Tismaneanu, Vladimir et. al. (2007) Raport Final - Comisia Prezidențială pentru Analiza Dictaturii Comunistei în România (București: Humanitas).

Villa-Vicencio, Charles (2003) 'Restorative Justice. Ambiguities and Limitations of a Theory' in Charles Villa-Vicencio and Erik Doxdater (eds) The Provocations of Amnesty. Memory, Justice and Impunity (Cape Town: New Africa Books) 30-50.

\section{Notes}

1 An account of this phenomenon is the chapter "Distortion, Negationism, and Minimalization of the Holocaust in Postwar Romania" of the Final Report of the International Commission on the Holocaust in Romania. The English version of this document can be found at http://www.ushmm.org/research/center/presentations/features/details/2005-03-10/.

2 Kenneth Jowitt defined Eastern Europe as a "brittle region" where "suspicion, division, and fragmentation predominate, not coalition and interrogation" because of lasting emotional, ethnic, territorial, demographic, political fragmentation form the (pre-)communist period. See his chapter "The Legacy of Leninism" in 1992, New World Disorder: the Leninist Extinction (Berkeley: University of California Press). For a recent discussion of this thesis also see Tismaneanu, Vladimir, Marc Howard, and Rudra Sil (eds) (2006) World Order After Leninism (Seattle: University of Washington Press).

3 An excellent example is the reaction of the Romanian Orthodox Church (B.O.R) to the Report's chapter about the relationship between the regime and the confessional communities. The irrefutable evidence of widespred cooperation with the R.C.P. and the B.O.R's infiltration by the Securitate generated vehement reactions from the institution's representatives and from the journalists and scholars with orthodoxist inclinations. The uproar went as far as the official 
declaration by the B.O.R about the creation of a special Commission under its umbrella for the creation of a counter-report. After the death of Teoctist in 2007, the Patriarch of B.O.R., his successor, Daniel, gave up on this initiative.

$4 \quad$ Priscilla Hayner makes a very convincing argument about the ways in which the activity of truth commissions can supplant for the fallacies and impotence of the judicial process, about the means by which a commission's activity and results can become the foundation for future legal action against abuses of the past.

5 See also Gross, Jan T. (2006) Fear: Anti-Semitism in Poland after Auschwitz - An Essay in Historical Interpretation (New York: Random House). 